\title{
The Impact of ICT Penetration on Deforestation: A Panel Data Evidence
}

\author{
Rasim Yilmaz, ${ }^{1}$ Cuneyt Koyuncu ${ }^{2}$
}

\begin{abstract}
A growing number of case studies and reports suggest that Information and Communication Technologies (ICT) play an important role in fighting against deforestation, and the penetration of ICT help decrease deforestation in a different part of world's forests. The aim of this study is to test whether diffusion of ICT contributes to decreasing in deforestation in the world. For this purpose, the effect of ICT penetration on deforestation is estimated by using bivariate and multivariate fixed time effect models. In the sample selection process, those countries having $2 \%$ or more forest area as a percentage of total land area we included in our analysis. The largest sample includes 174 countries. The period under study is between 1991 and 2012. It is found that ICT penetration is significantly and negatively associated with deforestation. The results are robust to the inclusion of a number of control variables as well as different indicators of ICT penetration and deforestation as such all available four ICT indicators and two deforestation indicators are used. To avoid potential spurious regression problems in the analyses, the original models are re-estimated by using the stationary forms of all independent and dependent variables. A strong negative correlation between ICT indicators and deforestation indicators is also supported by the findings of re-estimated bivariate and multivariate models. Empirical evidence at the macro level provided in this paper confirms the results mentioned in the case studies.
\end{abstract}

Keywords: Deforestation, Forest Management, Information and Communication Technologies, Panel Study

JEL Codes: Q23, Q56, O33, C23

Received: 7 July 2018 / Accepted: 14 October 2019/Sent for Publication: 5 December 2019

\section{Introduction}

Accelerated penetration of information and communication technologies (ICT) across countries in the world has triggered theoretical and empirical studies on the effects of ICT diffusion. Economic effects of ICT are widely discussed in the literature as such empirical studies suggest that diffusion of ICT can increase volume of trade (Frehund and Weinhold, 2004) and foreign direct investments (Choi, 2003), boost productivity

\footnotetext{
${ }^{1}$ Department of Economics, The Faculty of Economics and Administrative Sciences, Tekirdag Namik Kemal University, 59030 Tekirdag, Turkey, Phone:+90282-2502802, Facsimile:+902822931460, e-mail: rasimyilmaz@nku.edu.tr

${ }^{2}$ Department of Economics, The Faculty of Economics and Administrative Sciences, Bilecik Seyh Edebali University, 43270 Bilecik, Turkey, Facsimile: +90228-2129140, Phone: +902282124025, email: cuneyt.koyuncu@bilecik.edu.tr

(c) 2019 by the authors; licensee Review of Economic Perspectives / Národohospodárský obzor, Masaryk University, Faculty of Economics and Administration, Brno, Czech Republic. This article is an open access article distributed under the terms and conditions of the Creative Commons Attribution 3.0 license, Attribution - Non Commercial - No Derivatives.
} 
(Sanchez et al., 2006; Maciulyte-Sniukiene and Gaile-Sarkane, 2014) and economic growth (Czernich et al., 2011, Pradhan et al., 2014), and reduce unemployment (Czernich, 2014), corruption (Lio et al., 2011; Goel et al., 2012), inflation (Yi and Choi, 2005) and shadow economy (Elgin, 2013).

One of the recent discussions about the effects of ICT diffusion is the impact of ICT on the environment. It is argued that ICT usage can increase energy efficiency and hence help the environment. ICT usage can positively contribute to environmental sustainability by reducing greenhouse gas emissions through energy efficiency gains (Toffel and Horvath, 2004; Erdmann and Hilty, 2010). Also, ICT can be a tool for environmental protection by mapping and monitoring environmental threats.

On the other hand, it is also argued that the use of ICT can have negative effects on the environment through energy intensity of ICT use as well as production and waste disposal of ICT products. ICT usage may increase $\mathrm{CO} 2$ emissions and therefore harms the environment whereby ICT usage results in a rise in demand for electricity consumption which may lead to surge in CO2 emissions (Coroama and Hilty, 2014; Heddeghem et al. 2014; Salahuddin, Alam and Ozturk, 2016). Besides, production of IT products involves a number of environmentally harmful toxic and non-renewable inputs such as lead and mercury. Waste disposal of the electrical components and electronic IT goods also cause environmental pollution (Macauley, Palmer and Shih, 2003).

The ICT penetration can also affect deforestation. Several case studies assert that the ICT diffusion contributes to the management and conservation of forest and forestry resources. The adoption of ICT in the forest sector contributes to increase in the efficiency and effectiveness of forest management. The use of ICT in logging, raw material procurement, logistic process, production processes, and marketing of forestry products increase the operational productivity and efficiency in the forestry sector (Boston, 2005; Hetematik, Anders and Boston, 2005; Tuukka and Madhavi, 2017).

In regard to forest conservation, ICT and ICT applications can be used to map forest resources, to monitor forest risks, threats, and flow of goods from forests, to prevent illegal loggings and fires, to raise awareness of the need for sustainable forestry practices, to improve forest governance, to empower forest communities, to achieve sustainable forest management, to increase transparency and public participation, and to strengthen land rights (CTA, 2004; Reynolds et al., 2005; Mason and Messinger, 2014; Tuukka and Madhavi, 2017; Nunez, 2017).

Based on case studies, it may be hypothesized that the usage and diffusion of ICT in the forest sector can contribute to decrease in deforestation in the world. The aim of this article is to analyze the impact of ICT on deforestation with respect to several indicators of ICT by providing the first cross-country and macro-level empirical evidence on the relationship between ICT diffusion and deforestation. Although there are many case studies and reports about the influence of ICT on deforestation, to the best of our knowledge, there is no cross-country macro-level study on the relationship between ICT and deforestation in the literature. Therefore, this study attempts to fill this gap in the literature.

In this study, the impact of ICT penetration on deforestation is analyzed by using annual data of 174 countries for the period between 1991 and 2012. As a part of robustness, 
four ICT indicators and two deforestation indicators are used. The next section presents data and methodology. Section three provides estimation results while section four concludes.

\section{Data and Methodology}

This study intends to examine the relationship between ICT penetration and deforestation. For this purpose, we investigated the impact of ICT penetration on deforestation by using two deforestation indicators and four ICT indicators. The period under study is between 1991 and 2012. ${ }^{3}$ In the sample selection process, we included those countries having $2 \%$ or more forest area as a percentage of total land area into our analysis. Our largest sample includes 174 countries. ${ }^{4}$ EViews 9.0 statistical software is used for data processing in our analyses.

By using unbalanced panel data and a sample including developed and developing countries, we estimate the following bivariate and multivariate fixed time effect models $(\mathrm{FEM})^{5}$ built on the previous studies of Jorgenson and Burns (2007) and DeFries et al. (2010);

${ }^{3}$ In order to enhance robustness of estimation results, we used two different deforestation indicators. One of them is obtained from WDI while the other one is taken from FAO. Although the last data from WDI is from the year 2015, the last data from FAO is from the year 2012. Meanwhile, the numbers of not available data are very high for WDI data for the years 20142015. In order to keep consistency, we end the study period with the year 2012. However, when we overview developments of the recent years, reports and studies indicate a slowdown in deforestation.

${ }^{4}$ The sample includes the following countries: Afghanistan, Albania, Andorra, Antigua and Barbuda Angola, Argentina, Armenia, Aruba, Australia, Austria, Azerbaijan, Bahamas, Bahrain, Bangladesh, Barbados, Belarus, Belgium, Belize, Benin, Bermuda, Bhutan, Bolivia, Bosnia and Herzegovina, Botswana, Brazil, Brunei Darussalam, Bulgaria, Burkina Faso, Burundi, Cambodia, Cameroon, Canada, Cape Verde, Cayman Islands Central African Rep., Chad, Chile, China, Colombia, Comoros, Congo, Costa Rica, Cote d'Ivoire, Croatia, Cuba, Cyprus, Czech Republic, Denmark, Dominica, Dominican Republic, Ecuador, El Salvador, Equatorial Guinea, Eritrea, Estonia, Ethiopia, Fiji, Finland, France, French Polynesia, Gabon, Gambia, Georgia, Germany, Ghana, Greece, Grenada, Guam, Guatemala, Guinea, Guinea-Bissau, Guyana, Haiti, Honduras, Hungary, India, Indonesia, Iran, Iraq, Ireland, Israel, Italy, Jamaica, Japan, Kenya, Kiribati, Korea Republic, Kuwait, Kyrgyzstan, Lao P.D.R., Latvia, Lebanon, Liberia, Liechtenstein, Lithuania, Luxembourg, Macedonia, Madagascar, Malawi, Maldives, Malaysia, Mali, Mauritius, Marshall Islands, Mexico, Micronesia, Moldova, Mongolia, Montenegro, Morocco, Mozambique, Myanmar, Namibia, Nepal, Netherlands, New Caledonia, New Zealand, Nicaragua, Nigeria, Norway, Pakistan, Panama, Papua New Guinea, Paraguay, Peru, Philippines, Poland, Portugal, Puerto Rico, Romania, Russian Federation, Rwanda, Saint Lucia, Samoa, Saudi Arabia, Senegal, Serbia, Seychelles, Sierra Leone, Singapore, Slovakia, Slovenia, Solomon Islands, Somalia, South Africa, Spain, Sri Lanka, Sudan Republic, Suriname, Swaziland, Sweden, Switzerland, Syrian Arab Republic, Tajikistan, Thailand, Tanzania, Togo, Tonga, Trinidad and Tobago, Tunisia, Turkey, Turkmenistan, Tuvalu, Uganda, Ukraine, United Arab Emirates, United Kingdom, United States, Uruguay, Uzbekistan, Vanuatu, Venezuela, Viet Nam, Virgin Islands, Zambia, Zimbabwe.

${ }^{5}$ We used time effect model for two reasons. Firstly, as the period of estimation (1991-2012) is one in which interest in ICT products has been rising quite rapidly all over the world, we used period effect model instead of country-specific effect model in order to capture the impact of this 
DEFORESTATION $_{i t}=\left(\alpha+\tau_{t}\right)+\beta_{1} I_{C T}+u_{i t}$

DEFORESTATION

$$
\begin{aligned}
& =\left(\alpha+\tau_{t}\right)+\beta_{1} I_{C T}+\beta_{2} \text { CROPLAND }_{i t} \\
& +\beta_{3} \text { RURPOPGRO }_{i t}+\beta_{4} \text { GDPGRO }_{i t}+u_{i t}
\end{aligned}
$$

and the following bivariate and multivariate random time effect models (REM);

DEFORESTATION $N_{i t}=\alpha+\beta_{1}$ ICT $_{i t}+\left(\tau_{t}+u_{i t}\right)$

DEFOREST ATION

$$
\begin{aligned}
& =\alpha+\beta_{1} I C T_{i t}+\beta_{2} \text { CROPLAND }_{i t}+\beta_{3} R_{\text {RUPOPGRO }} \\
& +\beta_{4} \text { GDPGRO }_{i t}+\left(\tau_{t}+u_{i t}\right)
\end{aligned}
$$

where it subscript stands for the $i$-th country's observation value at time $t$ for the particular variable. $\alpha$ is the intercept term and $\tau_{t}$ represents time-specific effects that affect all countries in the same way (i.e., $\tau_{t}$ is variant across time but not across countries). $u_{i t}$ is idiosyncratic error term of the regression model.

Our dependent variable is the rate of deforestation. The annual rate of deforestation is calculated by subtracting the current year's forest area from previous year's forest area divided by the previous year's forest area multiplied by 100 whereby positive values indicate an increase in deforestation (i.e., a decrease in forestation) while negative values reflect a decrease in deforestation (i.e., an increase in forestation). Two different available forest area variables are used to evaluate the sensitivity of our empirical results. DEFORESTWDI is calculated by using the forest area (sq. $\mathrm{km}$ ). The data comes from WDI and covers the period between 1991 and 2012. DEFORESTFAO is calculated by utilizing the forest area $(1000 \mathrm{Ha})$. The source of the data, even it was downloaded from UNDATA, is FAOSTAT of FAO and includes the period between 1991 and 2012. Results may vary depending on which deforestation variable is used. If the results hold across different deforestation variables, it will be an indication of their robustness.

Our main explanatory variable of interest in this study is ICT penetration. ICT penetration in above models is represented by four variables, which are all available ICT indicators to our best knowledge. The definition and data source of ICT penetration variables are given in Table 1 below.

particular fact on deforestation. Besides, environmental consciousness increases as time goes on. Secondly, since country-specific effect model requires estimation of quite more coefficients (i.e., country-specific coefficients which are 174 in our largest sample) than period effect model (i.e., time-specific coefficients which are just 22 in our largest sample), thus reducing degrees of freedom and potentially draining statistical power of estimators, the period-effect model is chosen. 
Table 1. List of ICT Variables

\begin{tabular}{|l|l|l|}
\hline Variables & Definition & Source \\
\hline INTERNET & $\begin{array}{l}\text { Percentage of individuals using the } \\
\text { Internet }\end{array}$ & World Telecommunication \\
\hline CELLPHONE & $\begin{array}{l}\text { Mobile-cellular telephone subscriptions } \\
\text { per } 100 \text { inhabitants. }\end{array}$ & $\begin{array}{l}\text { International Telecommunication } \\
\text { Union }\end{array}$ \\
\hline COMPUTER & $\begin{array}{l}\text { Personal Computers per 100 } \\
\text { inhabitants. }\end{array}$ & http://www.nakono.com \\
\hline FXBROADBAND & $\begin{array}{l}\text { Fixed broadband subscriptions (per 100 } \\
\text { people) }\end{array}$ & $\begin{array}{l}\text { International Telecommunication } \\
\text { Union }\end{array}$ \\
\hline
\end{tabular}

In addition to ICT variable, we introduced three more determinants of deforestation suggested by previous studies (Jorgenson and Burns, 2007; DeFries et al., 2010) to analyze the association between deforestation and ICT penetration: rural population growth (RURPOPGRO), permanent cropland as a percentage of total land area (CROPLAND), and GDP growth (GDPGRO). The definition and data source of other independent variables are given in Table 2 below. The data related to all those variables come from World Development Index (WDI).

Table 2. List of Independent Variables

\begin{tabular}{|l|l|l|}
\hline Variables & Definition & Source \\
\hline CROPLAND & Permanent cropland (\% of land area) & WDI \\
\hline RURPOPGRO & Rural population growth (annual \%) & WDI \\
\hline GDPGRO & GDP growth (annual \%) & WDI \\
\hline
\end{tabular}

The following further describes the independent variables and discusses their expected signs.

CROPLAND refers to the permanent cropland as a percentage of land area. It is a proxy for agricultural land demand. Agricultural land expansion is often reported as the primary driver of deforestation and forest degradation (Myers, 1994; Deininger and Byerlee, 2011; McGrath, 2014). Shortage of productive farm and grazing lands motivate agents to clear forests in the absence of financial compensation and severe punishments. Moreover, the growth in demand for agricultural products requires either to increase the production of cultivated areas or to expand the cultivated areas. Most of the time, expanding the cultivated areas by clearing forests is preferred by agents since increasing the production of cultivated areas needs extra costs (Nath and Mwchahary, 2012). Hence, increasing demand for agricultural land and a shortage of productive farmlands cause forest lands to be cleared. Thus, the coefficient for this variable is expected to be positive.

RURPOPGRO is the annual rural population growth. In the deforestation literature, rural population growth is often pointed out as a primary cause of deforestation (Harrison, 1992; Cropper and Griffiths, 1994; Geist and Lambin, 2002; Carr, Suter and Barbieri, 2005; Jorgenson and Burns, 2007). Seventy-five percent of the worlds poor 
reside in rural areas and most of them subsist their life by engaging in agriculture (Deininger and Byerlee, 2011). Forest clearing and agricultural area expansion are important parts of most of the rural households' livelihood strategies (Babigumira et al., 2014) since rural population highly depend on forests for firewood, other forest products, grazing, agricultural and built-up area. Thus, rural population pressure leads to acceleration of forest clearance and forest degradation. Hence, we expect a positive correlation between RURPOPGRO and deforestation in our model.

GDPGRO refers to the annual Gross Domestic Product growth. The coefficient on the GDPGRO variable is expected to be ambiguous due to the environmental Kuznets Curve (EKC) hypothesis. According to the EKC hypothesis, the relationship between economic growth and environmental degradation can be displayed by an inverted Ushaped curve whereby economic growth may lead to environmental degradation at low levels of per capita income, but after a certain threshold level is achieved, further growth may produce incentives to improve environmental quality (Nohman and Antrobus, 2005; Salahuddin, Alam and Ozturk, 2016). Thus, in our model, the relationship between GDPGRO and deforestation is hypothesized to be ambiguous.

\section{Estimation Results}

Bivariate estimation results for four different ICT indicators are presented in Table 3,4,5 and 6. Each table consists of two columns (models) for two different deforestation indicators. We model each ICT and deforestation indicator separately in the different equations since modeling different indicators of ICT and deforestation in the same equation may cause multicollinearity problems.

The tables also provide Hausmann Test statistics for model selection between FEM and REM models and information on overall coefficients of determination (R-squared). Standard errors are given in parentheses with stars indicating significance levels as such coefficients having p-values lower than $10 \%$ are accepted as statistically significant coefficient estimations.

Table 3. Bivariate Model Estimation Results (Internet)

\begin{tabular}{|l|r|r|}
\hline & DEFORESTWDI & DEFORESTFAO \\
\hline C & $0.4108^{*}$ & $4.1176^{*}$ \\
& $(0.0302)$ & $(0.4972)$ \\
\hline INTERNET & $-0.0157^{*}$ & $-0.0185^{*}$ \\
$(0.0011)$ & $(0.0015)$ \\
\hline Number of Observations & 3080 & 2214 \\
\hline Number of Countries & 172 & 170 \\
\hline R-squared & 0.0690 & 0.0371 \\
\hline Estimated Model & FEM & REM \\
\hline Hausman-statistics & 123.422 & 1.9440 \\
\hline
\end{tabular}

Notes: *,**, *** stand for $1 \%, 5 \%$, and $10 \%$ significance levels, respectively. Standard errors are in parentheses. This holds for also for tables 4, 5 and 6. 
Table 4: Bivariate Model Estimation Results (Cellphone)

\begin{tabular}{|l|r|r|}
\hline & DEFORESTWDI & DEFORESTFAO \\
\hline C & $0.7475^{*}$ & $0.8345^{*}$ \\
& $(0.0505)$ & $(0.0505)$ \\
\hline CELLPHONE & $-0.0099^{*}$ & $-0.0129^{*}$ \\
& $(0.0007)$ & $(0.0010)$ \\
\hline Number of Observations & 2215 & 1360 \\
\hline Number of Countries & 174 & 172 \\
\hline R-squared & 0.0740 & 0.8082 \\
\hline Estimated Model & FEM & FEM \\
\hline Hausman-statistics & 85.068 & 102.773 \\
\hline
\end{tabular}

Table 5. Bivariate Model Estimation Results (Computer)

\begin{tabular}{|l|r|r|}
\hline & DEFORESTWDI & DEFORESTFAO \\
\hline C & $0.2761^{*}$ & $0.3968^{*}$ \\
$(0.0311)$ & $(0.0348)$ \\
\hline COMPUTER & $-0.0166^{*}$ & $-0.0182^{*}$ \\
$(0.0016)$ & $(0.0019)$ \\
\hline Number of Observations & 1885 & 1849 \\
\hline Number of Countries & 163 & 161 \\
\hline R-squared & 0.0582 & 0.7585 \\
\hline Estimated Model & FEM & FEM \\
\hline Hausman-statistics & 14.035 & 353.919 \\
\hline
\end{tabular}

Table 6. Bivariate Model Estimation Results (Fxbroadband)

\begin{tabular}{|l|r|r|}
\hline & DEFORESTWDI & DEFORESTFAO \\
\hline C & $\begin{array}{r}0.2785^{*} \\
(0.0409)\end{array}$ & $\begin{array}{r}0.2689^{*} \\
(0.0436)\end{array}$ \\
\hline FXBROADBAND & $\begin{array}{r}-0.0252^{*} \\
(0.0035)\end{array}$ & $\begin{array}{r}-0.0265^{*} \\
(0.0053)\end{array}$ \\
\hline Number of Observations & 1559 & 882 \\
\hline Number of Countries & 171 & 154 \\
\hline R-squared & 0.0405 & 0.0357 \\
\hline Estimated Model & FEM & FEM \\
\hline Hausman-statistics & 30.386 & 13.291 \\
\hline
\end{tabular}


All coefficients of INTERNET, CELLPHONE, COMPUTER and FXBROADBAND variables are negative and statistically significant at $1 \%$ level in all models in bivariate model estimations. Bivariate estimation results suggest that there is a strong negative correlation between ICT indicators and deforestation indicators.

To test the robustness of our results, we include a number of control variables suggested by previous studies (Jorgenson and Burns, 2007; DeFries et al., 2010). Multivariate estimation results for four different ICT indicators are separately presented at Table 7,8,9 and 10 to avoid multicollinearity problems. Each table consists of two columns (models) for two different deforestation indicators.

The estimation results for regressions where INTERNET is used as an independent variable are reported in Table 7. All coefficients of INTERNET variable are negative and statistically significant at the $1 \%$ level. The results suggest that deforestation decreases as the percentage of individuals using the internet increases.

Regarding other independent variables, the estimated coefficient of CROPLAND variable is positive and statistically significant at the $1 \%$ level in all models. The results indicate that surge in the agricultural land demand leads to deforestation. The coefficients of RURPOPGRO variable are statistically significant at the $1 \%$ level and have expected signs in all models. The results display that rural population growth is associated with deforestation. The coefficients of GDPGRO variable are negative and statistically significant at the $5 \%$ level in all models. The results imply that deforestation tends to decrease as nations become more developed.

Table 7. Multivariate Model Estimation Results (Internet)

\begin{tabular}{|l|r|r|}
\hline & DEFORESTWDI & DEFORESTFAO \\
\hline C & $0.2178^{*}$ & $0.2261^{*}$ \\
$(0.0440)$ & $(0.0453)$ \\
\hline INTERNET & $-0.0109^{*}$ & $-0.0121^{*}$ \\
& $(0.0013)$ & $(0.0017)$ \\
\hline CROPLAND & $0.0158^{*}$ & $0.0206^{*}$ \\
& $(0.0033)$ & $(0.0043)$ \\
\hline RURPOPGRO & $0.1575^{*}$ & $0.1875^{*}$ \\
& $(0.0156)$ & $(0.0177)$ \\
\hline GDPGRO & $-0.0083^{* *}$ & $-0.0084^{* *}$ \\
& $(0.0040)$ & $(0.0041)$ \\
\hline Number of Observations & 2863 & 2060 \\
\hline Number of Countries & 163 & 160 \\
\hline R-squared & 0.1095 & 0.7590 \\
\hline Estimated Model & FEM & FEM \\
\hline Hausman-statistics & 87.069 & 1131.013 \\
\hline
\end{tabular}

Notes: *, **, *** stand for 1\%, 5\%, and 10\% significance levels, respectively. Standard errors are in parentheses. This holds also for tables 8, 9 and 10. 
The estimation results for regressions by using CELLPHONE as an independent variable are presented in Table 8 . The estimated coefficients of CELLPHONE variable are found to be negative and statistically significant at the $1 \%$ level. The results show that surge in mobile phone subscriptions per 100 inhabitants is associated with a decrease in deforestation. In addition, results show that CROPLAND and RURPOPGRO positively and significantly influence deforestation at least at the 5\% level while GDPGRO has a negative and statistically significant effect at the $10 \%$ level on deforestation.

Table 8. Multivariate Model Estimation Results (Cellphone)

\begin{tabular}{|l|r|r|}
\hline & DEFORESTWDI & DEFORESTFAO \\
\hline C & $0.4909^{*}$ & $0.6682^{*}$ \\
$(0.0727)$ & $(0.0771)$ \\
\hline CELLPHONE & $-0.0069^{*}$ & $-0.0102^{*}$ \\
$(0.0008)$ & $(0.0011)$ \\
\hline CROPLAND & $0.0172^{*}$ & $0.0138^{* *}$ \\
& $(0.0037)$ & $(0.0048)$ \\
\hline RURPOPGRO & $0.1616^{*}$ & $0.1614^{*}$ \\
& $(0.0178)$ & $(0.0222)$ \\
\hline GDPGRO & $-0.0125^{* * *}$ & $-0.0212^{* *}$ \\
& $(0.0064)$ & $(0.0076)$ \\
\hline Number of Observations & 2049 & 1251 \\
\hline Number of Countries & 164 & 161 \\
\hline R-squared & 0.1158 & 0.8220 \\
\hline Estimated Model & FEM & FEM \\
\hline Hausman-statistics & 49.906 & 1138.289 \\
\hline
\end{tabular}

Table 9 reports estimation results for regressions where COMPUTER is used as an independent variable. All coefficients of COMPUTER are negative and statistically significant at the $1 \%$ level in both models, implying that higher personal computers per 100 inhabitants result in lower deforestation. Regarding other variables, CROPLAND and RURPOPGRO have a positive and statistically significant effect on deforestation, while GDPGRO is negatively and significantly associated with deforestation.

Table 10 displays the estimation results for regressions by using FXBROADBAND as an independent variable. All coefficients of FXBROADBAND are statistically significant at the $1 \%$ level and take the expected signs in line with what was expected. Interpretation of results indicates that an increase in fixed broadband subscriptions per 100 people leads to decrease in deforestation. CROPLAND variable is positive and statistically significant in only one model. The estimated coefficients of RURPOPGRO variable are statistically significant and have the expected signs in all models while the estimated coefficients of GDPGRO are negative and statistically significant in all models. 
Table 9. Multivariate Model Estimation Results (Computer)

\begin{tabular}{|l|r|r|}
\hline & DEFORESTWDI & DEFORESTFAO \\
\hline C & $0.1715^{* *}$ & $0.2391^{*}$ \\
& $(0.0479)$ & $(0.0541)$ \\
\hline COMPUTER & $-0.0123^{*}$ & $-0.0119^{*}$ \\
$(0.0018)$ & $(0.0020)$ \\
\hline CROPLAND & $0.0090^{* *}$ & $0.0162^{*}$ \\
& $(0.0040)$ & $(0.0052)$ \\
\hline RURPOPGRO & $0.1749^{*}$ & $0.2229 *$ \\
& $(0.0185)$ & $(0.0205)$ \\
\hline GDPGRO & $-0.0179^{*}$ & $-0.0226^{*}$ \\
& $(0.0058)$ & $(0.0065)$ \\
\hline Number of Observations & 1808 & 1772 \\
\hline Number of Countries & 157 & 155 \\
\hline R-squared & 0.1084 & 0.7772 \\
\hline Estimated Model & FEM & FEM \\
\hline Hausman-statistics & 17.411 & 1129.873 \\
\hline
\end{tabular}

Table 10. Multivariate Model Estimation Results (Fxbroadband)

\begin{tabular}{|l|r|r|}
\hline & DEFORESTWDI & DEFORESTFAO \\
\hline C & $0.2712^{*}$ & $0.3528^{*}$ \\
& $(0.0683)$ & $(0.0799)$ \\
\hline FXBROADBAND & $-0.0254^{*}$ & $-0.0327^{*}$ \\
& $(0.0042)$ & $(0.0064)$ \\
\hline CROPLAND & $0.0160^{*}$ & 0.0046 \\
& $(0.0053)$ & $(0.0057)$ \\
\hline RURPOPGRO & $0.1228^{*}$ & $0.1048^{*}$ \\
& $(0.0198)$ & $(0.0230)$ \\
\hline GDPGRO & $-0.0201^{* *}$ & $-0.0282^{*}$ \\
& $(0.0087)$ & $(0.0104)$ \\
\hline Number of Observations & 1445 & 810 \\
\hline Number of Countries & 158 & 142 \\
\hline R-squared & 0.0960 & 0.0931 \\
\hline Estimated Model & FEM & FEM \\
\hline Hausman-statistics & 27.138 & 15.335 \\
\hline
\end{tabular}


Hence, it is found that ICT penetration is significantly and negatively associated with deforestation. However, the results can't be interpreted as causal relationship since they may contain a spurious regression problem. To ensure the causal relationship between ICT penetration and deforestation, a proper empirical strategy needs to be employed, taking potential spurious regression problems into consideration.

The following steps are conducted in order to avoid the spurious regression problem in our analysis. First, the integration order of each variable in our models is assessed using panel unit root tests. ADF-Fisher and PP-Fisher panel unit root tests are performed to identify the order of integration (the stationarity level) of series used in our analysis whereby the null hypothesis of "the variable is non-stationary" is tested.

The panel root test results are reported in Table 11 below. The panel root test results suggest that DEFORESTWDI, DEFORESTFAO, CROPLAND, RURPOPGRO, and GDPGRO variables are I(0) while CELLPHONE, INTERNET, COMPUTER, and FXBROADBAND variables are stationary in first differences, i.e. I(1).

Table 11. Panel Unit Root Tests

\begin{tabular}{|l|c|c|c|c|}
\hline \multicolumn{1}{|c|}{ Variable } & Panel Unit Root Test & $\begin{array}{c}\text { Test } \\
\text { statistics }\end{array}$ & $\begin{array}{c}\text { Probability } \\
\text { value }\end{array}$ & $\begin{array}{c}\text { The Integration Order } \\
\text { of the Variable }\end{array}$ \\
\hline $\begin{array}{l}\text { DEFORESTWDI } \\
\text { (in levels) }\end{array}$ & $\begin{array}{c}\text { ADF - Fisher Chi- } \\
\text { square }\end{array}$ & 900.490 & 0.0000 & $\mathrm{I}(0)$ \\
\hline $\begin{array}{l}\text { DEFORESTWDI } \\
\text { (in levels) }\end{array}$ & $\begin{array}{c}\text { PP - Fisher Chi- } \\
\text { square }\end{array}$ & 928.922 & 0.0000 & $\mathrm{I}(0)$ \\
\hline $\begin{array}{l}\text { DEFORESTFAO(in } \\
\text { levels) }\end{array}$ & $\begin{array}{c}\text { ADF - Fisher Chi- } \\
\text { square }\end{array}$ & 1231.24 & 0.0000 & $\mathrm{I}(0)$ \\
\hline $\begin{array}{l}\text { DEFORESTFAO } \\
\text { (in levels) }\end{array}$ & $\begin{array}{c}\text { PP - Fisher Chi- } \\
\text { square }\end{array}$ & 1241.58 & 0.0000 & $\mathrm{I}(0)$ \\
\hline $\begin{array}{l}\text { CELLPHONE } \\
\text { (in levels) }\end{array}$ & $\begin{array}{c}\text { ADF - Fisher Chi- } \\
\text { square }\end{array}$ & 305.051 & 0.9530 & $\mathrm{I}(1)$ \\
\hline $\begin{array}{l}\text { CELLPHONE } \\
\text { (in levels) }\end{array}$ & $\begin{array}{c}\text { PP - Fisher Chi- } \\
\text { square }\end{array}$ & 381.058 & 0.1074 & $\mathrm{I}(1)$ \\
\hline $\begin{array}{l}\text { CELLPHONE } \\
\text { (in 1. differences) }\end{array}$ & $\begin{array}{c}\text { ADF - Fisher Chi- } \\
\text { square }\end{array}$ & 547.833 & 0.0000 & $\mathrm{I}(0)$ \\
\hline $\begin{array}{l}\text { CELLPHONE } \\
\text { (in 1. differences) }\end{array}$ & $\begin{array}{c}\text { PP - Fisher Chi- } \\
\text { square }\end{array}$ & 588.703 & 0.0000 & $\mathrm{I}(0)$ \\
\hline $\begin{array}{l}\text { INTERNET } \\
\text { (in levels) }\end{array}$ & $\begin{array}{c}\text { ADF - Fisher Chi- } \\
\text { square }\end{array}$ & 40.0026 & 1.0000 & $\mathrm{I}(1)$ \\
\hline $\begin{array}{l}\text { INTERNET } \\
\text { (in levels) }\end{array}$ & $\begin{array}{c}\text { PP - Fisher Chi- } \\
\text { square }\end{array}$ & 57.7290 & 1.0000 & 0.0000 \\
\hline $\begin{array}{l}\text { INTERNET } \\
\text { (in 1. differences) }\end{array}$ & $\begin{array}{c}\text { ADF - Fisher Chi- } \\
\text { square }\end{array}$ & 759.628 \\
\hline $\begin{array}{l}\text { INTERNET } \\
\text { (in 1. differences) }\end{array}$ & $\begin{array}{c}\text { square } \\
\text { PNi- }\end{array}$ & 753.760 & 0.0000 & \\
\hline
\end{tabular}




\begin{tabular}{|c|c|c|c|c|}
\hline $\begin{array}{l}\text { COMPUTER } \\
\text { (in levels) }\end{array}$ & $\begin{array}{l}\text { ADF - Fisher Chi- } \\
\text { square }\end{array}$ & 176.509 & 1.0000 & $\mathrm{I}(1)$ \\
\hline $\begin{array}{l}\text { COMPUTER } \\
\text { (in levels) }\end{array}$ & $\begin{array}{l}\text { PP - Fisher Chi- } \\
\text { square }\end{array}$ & 261.196 & 0.9891 & $\mathrm{I}(1)$ \\
\hline $\begin{array}{l}\text { COMPUTER } \\
\text { (in 1. differences) }\end{array}$ & $\begin{array}{l}\text { ADF - Fisher Chi- } \\
\text { square }\end{array}$ & 439.177 & 0.0000 & $\mathrm{I}(0)$ \\
\hline $\begin{array}{l}\text { COMPUTER } \\
\text { (in 1. differences) }\end{array}$ & $\begin{array}{l}\text { PP - Fisher Chi- } \\
\text { square }\end{array}$ & 456.238 & 0.0000 & $\mathrm{I}(0)$ \\
\hline $\begin{array}{l}\text { FXBROADBAND } \\
\text { (in levels) }\end{array}$ & $\begin{array}{l}\text { ADF - Fisher Chi- } \\
\text { square }\end{array}$ & 163.444 & 1.0000 & $\mathrm{I}(1)$ \\
\hline $\begin{array}{l}\text { FXBROADBAND } \\
\text { (in levels) }\end{array}$ & $\begin{array}{l}\text { PP - Fisher Chi- } \\
\text { square }\end{array}$ & 221.457 & 1.0000 & $\mathrm{I}(1)$ \\
\hline $\begin{array}{l}\text { FXBROADBAND } \\
\text { (in 1. differences) }\end{array}$ & $\begin{array}{l}\text { ADF - Fisher Chi- } \\
\text { square }\end{array}$ & 359.946 & 0.0012 & $\mathrm{I}(0)$ \\
\hline $\begin{array}{l}\text { FXBROADBAND } \\
\text { (in 1. differences) }\end{array}$ & $\begin{array}{l}\text { PP - Fisher Chi- } \\
\text { square }\end{array}$ & 402.437 & 0.0000 & $\mathrm{I}(0)$ \\
\hline $\begin{array}{l}\text { CROPLAND } \\
\text { (in levels) }\end{array}$ & $\begin{array}{l}\text { ADF - Fisher Chi- } \\
\text { square }\end{array}$ & 467.299 & 0.0000 & $\mathrm{I}(0)$ \\
\hline $\begin{array}{l}\text { CROPLAND } \\
\text { (in levels) }\end{array}$ & $\begin{array}{l}\text { PP - Fisher Chi- } \\
\text { square }\end{array}$ & 450.889 & 0.0000 & $\mathrm{I}(0)$ \\
\hline $\begin{array}{l}\text { RURPOPGRO } \\
\text { (in levels) }\end{array}$ & $\begin{array}{l}\text { ADF - Fisher Chi- } \\
\text { square }\end{array}$ & 917.106 & 0.0000 & $\mathrm{I}(0)$ \\
\hline $\begin{array}{l}\text { RURPOPGRO } \\
\text { (in levels) }\end{array}$ & $\begin{array}{l}\text { PP - Fisher Chi- } \\
\text { square }\end{array}$ & 818.594 & 0.0000 & $\mathrm{I}(0)$ \\
\hline $\begin{array}{l}\text { GDPGRO } \\
\text { (in levels) }\end{array}$ & $\begin{array}{c}\text { ADF - Fisher Chi- } \\
\text { square }\end{array}$ & 1585.93 & 0.0000 & $\mathrm{I}(0)$ \\
\hline $\begin{array}{l}\text { GDPGRO } \\
\text { (in levels) }\end{array}$ & $\begin{array}{l}\text { PP - Fisher Chi- } \\
\text { square }\end{array}$ & 1539.43 & 0.0000 & $\mathrm{I}(0)$ \\
\hline
\end{tabular}

In this case, to tackle the spurious regression problem, we employed the following empirical strategy. Spurious regression problem may exist in models using nonstationary time series. In other words, the regression of a nonstationary time series on another nonstationary time series may produce a spurious regression. Thus, in order to avoid potential spurious regression problem in our panel data analyses, we re-estimated the original models by using the first differences (i.e., stationary forms) of CELLPHONE, INTERNET, COMPUTER and FXBROADBAND variables in addition to our $\mathrm{I}(0)$ variables of DEFORESTWDI, DEFORESTFAO, CROPLAND, RURPOPGRO, GDPGRO such that all dependent and independent variables used in analyses are stationary.

Second, we intended to conduct a cointegration analysis. As known, in cointegration analysis, I(1) time series is regressed on the other I(1) time series, if the residual of this particular regression is stationary (i.e., $\mathrm{I}(0)$ ) then it is concluded that those two time 
series are cointegrated and therefore this particular regression analysis will be meaningful (i.e., not spurious). However, we are unable conduct cointegration analyses since conventional cointegration tests require all series used in analyses to be integrated order one, but we have mix integration orders (i.e., some variables are $\mathrm{I}(0)$, and some variables are I(1)).

Tables 12, 13, 14 and 15 report re-estimated bivariate estimation results for four different ICT indicators, each one of which is at the first differences. All coefficients of variables are negative and statistically significant at the $1 \%$ level in all models except CELLPHONE variable for the model where DEFORESTWDI is dependent variable. Thus, strong negative correlation between ICT indicators and deforestation indicators is also supported by re-estimated bivariate estimation results.

Table 12. Bivariate Model Estimation Results (Internet-Stationary)

\begin{tabular}{|l|r|r|}
\hline & DEFORESTWDI & DEFORESTFAO \\
\hline C & $\begin{array}{r}0.3154^{*} \\
(0.0294)\end{array}$ & $\begin{array}{r}0.4381^{*} \\
(0.0317)\end{array}$ \\
\hline INTERNET & $\begin{array}{r}-0.0797 * \\
(0.0076)\end{array}$ & $\begin{array}{r}-0.0925^{*} \\
(0.0087)\end{array}$ \\
\hline Number of Observations & 2.913 & 2052 \\
\hline Number of Countries & 172 & 169 \\
\hline R-squared & 0.0480 & 0.7527 \\
\hline Estimated Model & FEM & FEM \\
\hline Hausman-statistics & 57.740 & 23.1780 \\
\hline
\end{tabular}

Notes: *,**, *** stand for 1\%, 5\%, and 10\% significance levels, respectively. Standard errors are in parentheses. This holds also for tables 13,14 and 15.

Table 13. Bivariate Model Estimation Results (Cellphone- Stationary)

\begin{tabular}{|l|r|r|}
\hline & DEFORESTWDI & DEFORESTFAO \\
\hline C & $0.2217 *$ & $0.5606^{*}$ \\
$(0.0387)$ & $(0.0530)$ \\
\hline CELLPHONE & -0.0030 & $-0.0261^{*}$ \\
& $(0.0035)$ & $(0.0052)$ \\
\hline Number of Observations & 2038 & 1.189 \\
\hline Number of Countries & 174 & 172 \\
\hline R-squared & 0.0003 & 0.8072 \\
\hline Estimated Model & REM & FEM \\
\hline Hausman-statistics & 0.0004 & 366.098 \\
\hline
\end{tabular}


Table 14. Bivariate Model Estimation Results (Computer- Stationary)

\begin{tabular}{|l|r|r|}
\hline & DEFORESTWDI & DEFORESTFAO \\
\hline C & $0.2150^{*}$ & $0.3368^{*}$ \\
& $(0.0308)$ & $(0.0343)$ \\
\hline COMPUTER & $-0.0933^{*}$ & $-0.1018^{*}$ \\
& $(0.0121)$ & $(0.0137)$ \\
\hline Number of Observations & 1763 & 1731 \\
\hline Number of Countries & 162 & 160 \\
\hline R-squared & 0.0438 & 0.7715 \\
\hline Estimated Model & FEM & FEM \\
\hline Hausman-statistics & 4.8551 & 900.961 \\
\hline
\end{tabular}

Table 15. Bivariate Model Estimation Results (Fxbroadband- Stationary)

\begin{tabular}{|l|r|r|}
\hline & DEFORESTWDI & DEFORESTFAO \\
\hline C & $\begin{array}{r}0.1653^{*} \\
(0.0340)\end{array}$ & $\begin{array}{r}0.2709^{*} \\
(0.0452)\end{array}$ \\
\hline FXBROADBAND & $-0.1019^{*}$ & $0.0446^{*}$ \\
$(0.0154)$ & $(0.0177)$ \\
\hline Number of Observations & 1309 & 712 \\
\hline Number of Countries & 160 & 144 \\
\hline R-squared & 0.0325 & 0.0357 \\
\hline Estimated Model & REM & REM \\
\hline Hausman-statistics & 0.0043 & 1.2264 \\
\hline
\end{tabular}

Robustness of the results are also supported by re-estimated multivariate model estimation results which are presented in Tables 16, 17, 18 and 19. All coefficients of CELLPHONE, INTERNET, COMPUTER, and FXBROADBAND variables are negative and statistically significant at least at 5\% level in all models. Thus, results are robust to the inclusion of several control variables and ensure the negative correlation between ICT indicators and deforestation indicators. 
Table 16. Multivariate Model Estimation Results (Internet-Stationary)

\begin{tabular}{|l|r|r|}
\hline & DEFORESTWDI & DEFORESTFAO \\
\hline C & $0.1309^{*}$ & $0.2417^{*}$ \\
& $(0.0415)$ & $(0.0478)$ \\
\hline INTERNET & $-0.0551^{*}$ & $-0.0635^{*}$ \\
$(0.0081)$ & $(0.0095)$ \\
\hline CROPLAND & $0.0206^{*}$ & $0.0245^{*}$ \\
& $(0.0034)$ & $(0.0046)$ \\
\hline RURPOPGRO & $0.1816^{*}$ & $0.1960^{*}$ \\
& $(0.0153)$ & $(0.0179)$ \\
\hline GDPGRO & -0.0085 & $-0.0166^{*}$ \\
& $(0.0054)$ & $(0.0059)$ \\
\hline Number of Observations & 2715 & 1916 \\
\hline Number of Countries & 163 & 159 \\
\hline R-squared & 0.1073 & 0.7745 \\
\hline Estimated Model & FEM & FEM \\
\hline Hausman-statistics & 50.9390 & 1068.468 \\
\hline
\end{tabular}

Notes: *, **, *** stand for 1\%, 5\%, and 10\% significance levels, respectively. Standard errors are in parentheses.

Table 17. Multivariate Model Estimation Results (Cellphone-Stationary)

\begin{tabular}{|l|r|}
\hline & DEFORESTFAO \\
\hline C & $\begin{array}{r}0.3293^{*} \\
(0.0760)\end{array}$ \\
\hline CELLPHONE & $-0.0159^{* *}$ \\
& $(0.0062)$ \\
\hline CROPLAND & $0.0214^{*}$ \\
& $(0.0053)$ \\
\hline RURPOPGRO & $0.2070^{*}$ \\
& $(0.0234)$ \\
\hline GDPGRO & -0.0101 \\
& $(0.0083)$ \\
\hline Number of Observations & 1093 \\
\hline Number of Countries & 159 \\
\hline R-squared & 0.8270 \\
\hline Estimated Model & FEM \\
\hline Hausman-statistics & 824.2668 \\
\hline
\end{tabular}

Notes: Multivariate analysis for CELLPHONE variable for the model where DEFORESTWDI is dependent variable is not conducted since the bivariate estimation result is not statistically significant for this model. *,**,*** stand for 1\%, 5\%, and $10 \%$ significance levels, respectively. Standard errors are in parentheses. 
Table 18. Multivariate Model Estimation Results (Computer-Stationary)

\begin{tabular}{|l|r|r|}
\hline & DEFORESTWDI & DEFORESTFAO \\
\hline C & $0.0926^{* *}$ & $0.1610^{*}$ \\
& $(0.0452)$ & $(0.0505)$ \\
\hline COMPUTER & $-0.0630^{*}$ & $-0.0585^{*}$ \\
$(0.0125)$ & $(0.0140)$ \\
\hline CROPLAND & $0.0104^{* *}$ & $0.0192^{*}$ \\
& $(0.0041)$ & $(0.0054)$ \\
\hline RURPOPGRO & $0.1866^{*}$ & $0.2400^{*}$ \\
& $(0.0188)$ & $(0.0206)$ \\
\hline GDPGRO & $-0.0128^{* *}$ & $-0.0180^{*}$ \\
& $(0.0060)$ & $(0.0066)$ \\
\hline Number of Observations & 1695 & 1663 \\
\hline Number of Countries & 156 & 154 \\
\hline R-squared & 0.0999 & 0.7920 \\
\hline Estimated Model & FEM & FEM \\
\hline Hausman-statistics & 11.0730 & 1550.284 \\
\hline
\end{tabular}

Notes: *, **, *** stand for 1\%, 5\%, and 10\% significance levels, respectively. Standard errors are in parentheses.

Table 19. Multivariate Model Estimation Results (Fxbroadband-Stationary)

\begin{tabular}{|l|r|r|}
\hline & DEFORESTWDI & DEFORESTFAO \\
\hline C & $0.1179^{* *}$ & $0.3177^{*}$ \\
& $(0.0468)$ & $(0.0764)$ \\
\hline FXBROADBAND & $-0.0955^{*}$ & $-0.1171^{*}$ \\
& $(0.0159)$ & $(0.0205)$ \\
\hline CROPLAND & 0.0054 & -0.0017 \\
& $(0.0045)$ & $(0.0058)$ \\
\hline RURPOPGRO & $0.1113^{*}$ & $0.0215^{* *}$ \\
& $(0.0153)$ & $(0.0001)$ \\
\hline GDPGRO & 0.0020 & -0.0136 \\
& $(0.0063)$ & $(0.0096)$ \\
\hline Number of Observations & 1213 & 655 \\
\hline Number of Countries & 149 & 134 \\
\hline R-squared & 0.0928 & 0.0878 \\
\hline Estimated Model & REM & REM \\
\hline Hausman-statistics & 3.3619 & 5.0159 \\
\hline
\end{tabular}

Notes: *, **, *** stand for 1\%, 5\%, and 10\% significance levels, respectively. Standard errors are in parentheses. 
Overall, our findings suggest that the penetration of ICT contributes to decline in deforestation between 1991 and 2012. The findings in this study also demonstrate that among ICT variables, the strongest impact is generated by FXBROADBAND variable followed by COMPUTER, INTERNET, and CELLPHONE in both models.

\section{Conclusion}

This study empirically investigates the explanatory power of information and communication technologies on deforestation. Case studies and reports indicate that ICT can play an important role in fighting against deforestation. Although there are many case studies and reports about the influence of ICT on deforestation, to the best of our knowledge, there is no cross-country macro-level study on the relationship between ICT and deforestation in the literature. Therefore, this study attempts to fill this gap in the literature.

The aim of this article is to support case studies with cross-country and macro-level empirical evidence. By using four ICT indicators, two deforestation indicators and a panel data set consisting of 174 countries, we test the hypothesis that ICT penetration contributes to decrease in deforestation. The statistically significant negative association between ICT penetration indicators and deforestation indicators is identified. Results are robust to the inclusion of a number of control variables. To avoid potential spurious regression problems in the analyses, the original models are re-estimated by using the stationary forms of all independent and dependent variables. The strong negative correlation between ICT indicators and deforestation indicators is also supported by the findings of re-estimated bivariate and multivariate models. Thus, our study empirically proves the negative association between ICT diffusion and deforestation and may support for the ICT usage in the forestry sector.

There is a growing worldwide concern regarding forest conservation. ICT applications can be used in a number of ways in forest conservation ranging from monitoring forest risks and threats and preventing illegal loggings and fires to increase transparency and public participation.

One of the drawbacks in regard to usage of ICT applications in forest conservation is the fact that its level of priority is lower than other areas such as health and education. That is why cooperation in conservation is essential to improve forest governance through ICT usage. This holds true at international level among countries and the macro-level between large organizations as well as local-level between agents developing solutions to local problems.

Disclosure statement: The authors reported no potential conflict of interest. 


\section{References}

BABIGUMIRA, R., ANGELSEN, A., BUIS, M., BAUCH, S., SUNDERLAND, T. and WUNDER, S. (2014). Forest Clearing in Rural Livelihoods: Household-Level GlobalComparative Evidence. World Development, 64 (1): 67-79. DOI: 10.1016/j.worlddev.2014.03.002

BOSTON, K. (2005). ICT in Forest Business. In. L. HETEMAKI and S. NILSSON (Eds.) Information Technology and the Forest Sector, IUFRO World Series Vol. 18, the International Union of Forest Research Organizations (IUFRO), Vienna, Austria, 64-76.

CARR, D. L., SUTER, L., and BARBIERI, A. (2005). Population Dynamics and Tropical Deforestation: State of the Debate and Conceptual Challenges. Population and Environment, 27(1): 13-89

CHOI, C. (2003). Does the Internet Stimulate inward FDI? Journal of Policy Modelling, 25: 319-326. DOI: 10.1016/S0161-8938(02)00202-8

COROAMA, V.C. and HILTY, L.M. (2014). Assessing Internet Energy Intensity: A Review of Methods and Results. Environmental Impact Assessment Review, 45: 63-68. DOI: $\underline{10.1016 / j . e i a r .2013 .12 .004}$

CROPPER, M. and GRIFFITHS, C. (1994). The Interaction of Population Growth and Environmental Quality. American Economic Review, 84(2): 250-254.

CTA (2004). Editorial: Rooting ICTs in Forest Management. ICT Update Issue 19. CTA (Technical Center for Agricultural and Rural Cooperation), Wageningen, The Netherlands. Accessed https://cgspace.cgiar.org/bitstream/handle/10568/91584/ICTUpdate19E.pdf?sequence=1 \&isAllowed $=\mathrm{y}$

CZERNICH, N. (2014). Does Broadband Internet Reduce the Unemployment Rate? Evidence for Germany. Information Economics and Policy, 29: 32-45. DOI: 10.1016/j.infoecopol.2014.10.001

CZERNICH, N., FALCK, O., KRETSCHMER, T. and WOESSMANN, L. (2011). Broadband Infrastructure and Economic Growth. The Economic Journal, 121, 505-532.

DEININGER, K. and BYERLEE, D. (2011). Rising Global Interest in Farmland: Can It Yield Sustainable and Equitable Benefits? The World Bank Publications, Washington D.C.

DEFRIES, R.S., RUDEL, T., URIARTE, M. and HANSEN, M. (2010). Deforestation Driven by Urban Population Growth and Agricultural Trade in the Twenty-First Century. Nature Geoscience, 3: 178-181. DOI: 10.1038/ngeo756

ELGIN, C. (2013). Internet Usage and the Shadow Economy: Evidence from Panel Data. Economic Systems, 37 (1): 111-121. DOI: 10.1016/j.ecosys.2012.08.005

ERDMANN, L. and HILTY, L.M. (2010). Scenario Analysis: Exploring the Macroeconomic Impacts of Information and Communication Technologies on Greenhouse Gas Emissions. Journal of Industrial Economy, 14 (5): 826-843. DOI: $\underline{10.1111 / j .1530-9290.2010 .00277 . x}$ 
FREHUND,C.L. and WEINHOLD, D. (2004). The Effect of the Internet on International Trade. Journal of International Economy, 62 (1): 171-189. DOI: 10.1016/S0022-1996(03)00059-X

GEIST, H. J., and LAMBIN, E. F. (2002). Proximate Causes and Underlying Driving Forces of Tropical Deforestation. Bio-Science, 52(2), 143-150.

GOEL, R., NELSON, M. and NARETTA, M. (2012). The Internet as an Indicator of Corruption Awareness. European Journal of Political Economy, 28 (1): 64-75. DOI: 10.1016/j.ejpoleco.2011.08.003

HARRISON, P. (1992). The Third Revolution: Population, Environment and a Sustainable World, Penguin, Harmondsworth.

HEDDEGHEM V.W., LAMBERT, S., LANNOO, B., COLLE, D., PICKAVET, M. and DEMEESTER, P. (2014). Trends in Worldwide ICT Electricity Consumption from 2007 to 2012. Computer Communications, 50: 64-76.

HETEMAKI, L., ANDERS, Q.N., and BOSTON, K. (2005). ICT and the Forest Sector: The History and the Present. L. Hetemaki and S. Nilsson Eds. Information Technology and the Forest Sector, IUFRO World Series Vol. 18, the International Union of Forest Research Organizations (IUFRO), Vienna, Austria, 8-24.

JORGENSON, A.K. and BURNS, T.J. (2007). Effects of Rural and Urban Population Dynamics and National Development on Deforestation in Less-Developed Countries, 1990-2000. Sociological Inquiry, 77(3): 460-482. DOI: $10.1111 / \mathrm{j} .1475-$ 682X.2007.00200.x

LIO,M., LIU,M. and OU, Y. (2011). Can the Internet Reduce Corruption? A Cross Country Study Based on Dynamic Panel Data Models, Government Information Quarterly, 28 (1): 47-53. DOI: $\underline{10.1016 / j . g i q .2010 .01 .005}$

MACAULEY, M., PALMER, K. and SHIH, J-S. (2003). Dealing with Electronic Waste: Modeling the Costs and Environmental Benefits of Computer Monitor Disposal. Journal of Environmental Management, 68 (1): 13-22. DOI: 10.1016/S03014797(02)00228-1

MACIULYTE-SNIUKIENE, A. and GAILE-SARKANE, E. (2014). Impact of Information and Telecommunication Technologies Development on Labor Productivity. Procedia-Social and Behavioral Sciences, 110: 1271-1282.

MASON, J. and MESSINGER, J. (2014). Global Gathering to Explore How Technology is Improving Forest Governance, Global Forest Watch, Accessed on https://blog.globalforestwatch.org/gfw-community/events/global-gathering.html

MCGRATH, M. (2014). Demand for Agricultural Products Drives Shock Tree Loss in Tropical Forests. Accessed on https://www.bbc.com/news/science-environment$\underline{29144568}$

MYERS, N. (1994). Tropical Deforestation: Rates and Patterns. Brown, K. and Pearce, D. Eds. The Causes of Tropical of Tropical Deforestation: The Economic and Statistical Analysis of Factors Giving Rise to the Loss of the Tropical Forest, UBC Press, Vancouver, British Colombia, 27-40. 
NATH, D.C. and MWCHAHARY, D.D. (2012). Population Increase and Deforestation: A Study in Korajhar District of Assam, India. International Journal of Scientific and Research Publications, 2 (10): 1-12.

NOHMAN, A. and ANTROBUS, G. (2005). Trade and the Environmental Kuznets Curve: Is Southern Africa a Pollution Heaven? South African Journal of Economics, 73: 803-814. DOI: 10.1111/j.1813-6982.2005.00055.X

NUNEZ, C. (2017). Your Old Cell Phone Can Help Save the Rain Forest, Accessed on https://news.nationalgeographic.com/2017/06/topher-white-engineer-rainforestsexplorer-festival/

PRADHAN, R.P., ARVIN, M.B., NORMAN, N.R. and BELE, S.K. (2014). Economic Growth and the Development of Telecommunications Infrastructure in the G-20 Countries: A Panel-VAR Approach. Telecommunications Policy, 38: 634-649. DOI: $\underline{10.1016 / j . t e l p o l .2014 .03 .001}$

REYNOLDS, K.M, BORGES, J.G., VACIK, H. and LEXER, M.J. (2005). ICT in Forest Management and Conservation. L. Hetemaki and S. Nilsson Eds. Information Technology and the Forest Sector, IUFRO World Series Vol. 18, the International Union of Forest Research Organizations (IUFRO), Vienna, Austria, 150-172.

SALAHUDDIN, M., ALAM, K. and OZTURK, I. (2016). Is Rapid Growth in Internet Usage Environmentally Sustainable for Australia? An Empirical Investigation. Environmental Science and Pollution Research, 23(5): 4700-4713. DOI: 10.1007/s11356-015-5689-7

SANCHEZ, J.I.L., RATA, B.M., DUARTE, A.R. and SANDULLI, F.D. (2006). Is the Internet Productive? A Firm Level Analysis. Technovation, 26 (7): 821-826. DOI: 10.1016/j.technovation.2005.03.002

TOFFEL, M.W. and HORVATH, A. (2004). Environmental Implications of Wireless Technologies: News Delivery and Business Meetings. Environmental Science \& Technology, 38 (11): 2961-2970. DOI: 10.1021/es0350350

TUUKKA, C. And MADHAVI, P. (2017). Using ICT to Improve Forest Governance, The World Bank Edition, ICT in Agriculture: Connecting Smallholders to Knowledge, Networks, and Institutions, World Bank, Washington D.C., 371-401.

YI, M.H. and CHOI, C. (2005). The Effect of the Internet on Inflation: Panel Data Analysis. Journal of Policy Modelling, 27: 885-889. DOI: 10.1016/j.jpolmod.2005.06.008 